\title{
KEANEKARAGAMAN FITOPLANKTON SEBAGAI INDIKATOR \\ TINGKAT PENCEMARAN PERAIRAN TELUK LALONG KOTA LUWUK
}

\author{
Sri Sukari Agustina dan Andi Aonurofik M.Poke
}

Fakultas Perikanan UNISMUH Luwuk Kabupaten Banggai

Email : asrisukari@yahoo.com, aonurafiqpoke@yahoo.com

\begin{abstract}
ABSTRAK
Penelitian ini bertujuan untuk menganalisis keanekaragaman fitoplankton sebagai indikator tingkat pencemaran perairan Teluk Lalong Kota Luwuk. Penelitian ini dilaksanakan pada bulan Februari sampai dengan bulan Mei 2015. Metode yang digunakan untuk pengambilan data dalam penelitian ini adalah metode survei dan laboratories. Pengambilan sampel fitoplankton di perairan Teluk Lalong Kota Luwuk dilakukan pada enam titik sampling menggunakan metode sampel random. Sampel fitoplankton yang diperoleh diidentifikasi jenis fitoplankton, sedangkan analisis kuantitatif indeks biologi fitoplankton berdasarkan perhitungan keanekaragaman dari Shannon-Wiener. Perbedaan keaneka-ragaman fitoplankton yang didapatkan dianalisis secara deskriptif. Hasil analisis penelitian menunjukkan bahwa jenis fitoplankton yang didapatkan di perairan Teluk Lalong Kota Luwuk ada 21 spesies yang secara keseluruhan didominasi dari jenis Nitzschia closterium, Gonatozygon monotenium dan Goniodoma sp. Rata-rata nilai Indeks Keanekaragaman dari enam stasiun (S1, S2, S3. S4, S5 dan S6) berkisar antara 0,62-1,06. Berdasarkan rata-rata nilai Indeks Keanekaragaman fitoplankton, perairan Teluk Lalong dikategorikan tercemar sedang dan tercemar berat. Data penunjang parameter kualitas air di perairan Teluk Lalong Kota Luwuk yang meliputi suhu, pH, salinitas dan kecerahan masih dalam kisaran normal untuk kehidupan fitoplankton.
\end{abstract}

Kata kunci : keanekaragaman, fitoplankton, pencemaran

\section{PENDAHULUAN}

Tekanan terhadap ekosistem perairan Teluk Lalong disebabkan oleh beberapa faktor, seperti kepadatan dan jumlah penduduk Kota Luwuk yang tinggi dan terus bertambah disamping berbagai kegiatan industri yang terus berkembang dan pola penggunaan tanah yang intensif, baik langsung maupun tak langsung. Akibatnya kondisi lingkungan perairan laut di perairan Teluk Lalong mengalami kemunduran dan perubahan kualitas perairan sepanjang tahun.

Perubahan terhadap kualitas perairan Teluk Lalong erat kaitannya dengan potensi perairan ditinjau dari kelimpahan dan komposisi fitoplankton di perairan Teluk Lalong. Keberadaan fitoplankton di suatu perairan bisa memberikan informasi mengenai kondisi perairan. Basmi (2000), fitoplankton merupakan parameter biologi yang dapat dijadikan indikator untuk mengevaluasi kualitas dan tingkat kesuburan suatu perairan. Pentingnya peranan fitoplankton sebagai pengikat awal energi matahari menjadikan fitoplankton berperan penting bagi kehidupan laut, sehingga keberadaan fitoplankton di perairan Teluk Lalong memang dapat dijadikan indikator kualitas perairan.

Keragaman jenis merupakan parameter yang digunakan dalam mengetahui suatu komunitas. Parameter ini mencirikan kekayaan jenis dan keseimbangan dalam suatu komunitas. Akhir-akhir ini terjadi penurunan perairan yang menjadikan keragaman fitoplankton di perairan Teluk Lalong Kota Luwuk rendah. Ekosistem dengan keragaman rendah adalah tidak stabil dan rentan terhadap pengaruh tekanan dari luar dibandingkan dengan ekosistem yang memiliki keragaman tinggi (Boyd, 
1979). Suatu komunitas dikatakan mempunyai keanekaragaman jenis rendah jika komunitas itu disusun oleh sangat sedikit spesies dan hanya sedikit spesies yang dominan, begitu pula sebaliknya. Penyebaran individu setiap spesies atau genera tidak sama dan ada kecenderungan suatu spesies mendominasi komunitas.

Tujuan penelitian adalah untuk menganalisis keanekaragaman fitoplankton sebagai indikator tingkat pencemaran perairan Teluk Lalong Kota Luwuk.

\section{MATERI DAN METODE}

Penelitian ini dilaksanakan pada bulan Februari sampai dengan bulan Mei 2015 dengan lokasi penelitian perairan Teluk Lalong Kota Luwuk Kabupaten Banggai. Sedangkan untuk analisis laboratorium dilaksanakan di Laboratorium Fakultas Perikanan Universitas Muhammadiyah Luwuk. Metode pengambilan data dalam penelitian ini adalah metode survei dan laboratories. Pengambilan sampel fitoplankton di perairan Teluk Lalong Kota Luwuk dilakukan pada enam titik sampling menggunakan metode sampel random (Clark dan Hosking, 1986). Fitoplankton dikoleksi menggunakan plankton net no. 25. Sampel fitoplankton yang diperoleh diidentifikasi jenis fitoplankton dengan bantuan mikroskop berpedoman pada Sachlan (1982), dan Newel (1977), serta Yamaji (1976).

Keanekaragaman spesies fitoplankton dihitung dengan menggunakan indeks keanekaragaman Shannon-Wiener (Odum, 1971 dalam Basmi, 2000) dengan rumus :

$$
H^{\prime}=-\sum_{i=1}^{S} P i \ln P i
$$

Keterangan :

$\mathrm{H}^{\prime}$ = indeks diversitas Shanon-Wiener

$\mathrm{Pi}=$ jumlah individu masing-masing jenis $(i=1,2,3, \ldots)(P i=n i / N)$

ni $=$ jumlah individu jenis ke-i

$\mathrm{N}=$ jumlah total individu semua taksa (biomassa) pada suatu komunitas

\section{Kriteria:}

$\mathrm{H}^{\prime}<1=$ keanekaragaman rendah, komunitas biota tidak stabil dan kualitas air tercemar berat

$1 \leq H^{\prime} \leq 3=$ keanekaragaman sedang, stabilitas komunitas biota sedang dan kualitas air tercemar sedang

$\mathrm{H}^{\prime}>3=$ keanekaragaman tinggi, stabilitas komunitas biota dalam kondisi prima (stabil) dan kualitas air bersih

Sebagai data penunjang dilakukan pengukuran kualitas air yang meliputi $\mathrm{pH}$, suhu dan salinitas dilaksanakan dua kali sehari pada saat pengambilan sampel fitoplankton di masingmasing lokasi penelitian. Data keanekaragaman fitoplankton yang diperoleh dihimpun dalam bentuk tabulasi selanjutnya dianalisis secara deskriptif.

\section{HASIL DAN PEMBAHASAN}

\section{Tingkat Pencemaran Teluk Lalong}

Hasil analisis nilai Indeks Keanekaragaman $\left(\mathrm{H}^{\prime}\right)$ fitoplankton di perairan Teluk Lalong Kota Luwuk pada masing-masing stasiun terdapat pada Tabel 1. Hasil analisis Tabel 1 rata-rata nilai Indeks Keanekaragaman $\left(\mathrm{H}^{\prime}\right)$ fitoplankton di perairan Teluk Lalong Kota Luwuk pada stasiun S1 sebesar 1,06 artinya bahwa komunitas fitoplankton di perairan Teluk Lalong keanekaragamannya sedang, stabilitas komunitas biota sedang dan kualitas air tercemar sedang, sedangkan pada Stasiun S2, S3, S4, S5 dan S6 di bawah angka 1 artinya bahwa 
Tabel 1. Nilai Indeks Keanekaragaman $\left(\mathrm{H}^{\prime}\right)$ fitoplankton di perairan Teluk Lalong Kota Luwuk

\begin{tabular}{ccccccc}
\hline & \multicolumn{7}{c}{ Stasiun } \\
\cline { 2 - 7 } & S1 & S2 & S3 & S4 & S5 & S6 \\
\hline$H^{\prime} 1$ & 1,12 & 1,04 & 0,45 & 0,8 & 0,68 & 1,04 \\
$H^{\prime} 2$ & 1,16 & 0,64 & 1,23 & 0,94 & 0,8 & 0,8 \\
$H^{\prime} 3$ & 0,99 & 0,3 & 0,59 & 0,3 & 1,39 & 0,3 \\
$H^{\prime} 4$ & 0,95 & 0,96 & 1 & 0,45 & 0,56 & 0,64 \\
Rata-rata & 1,06 & 0,74 & 0,82 & 0,62 & 0,86 & 0,70 \\
\hline
\end{tabular}

Keterangan :

$\mathrm{H}^{\prime} 1, \mathrm{H}^{\prime} 2, \mathrm{H}^{\prime} 3, \mathrm{H}^{\prime} 4 \quad$ : Indeks Keanekaragaman fitoplankton pada setiap pengambilan sampel

S1 : Perairan depan pelabuhan peti kemas (S:0057.13'25" ; E: $\left.122^{\circ} 47.41^{\prime 2} 21^{\prime \prime}\right)$

S2 : Perairan depan gedung DPRD (S : 00057.11'98" ; E: $\left.122^{\circ} 47.31^{\prime} 38^{\prime \prime}\right)$

S3 : Perairan depan CFC (S : 00 $57.12^{\prime} 65^{\prime \prime}$; E: $\left.122^{\circ} 47.31^{\prime} 49^{\prime \prime}\right)$

S4 : Perairan depan muara Sungai Maleo (S : 0057.02'32" ; E: $122^{\circ} 47.38^{\prime} 08^{\prime \prime}$ )

S5 : Perairan depan rumah makan Pasar Tua (S: 0056.54'57" ; E: $122^{\circ} 47.51^{\prime} 31^{\prime \prime}$ )

S6 : Perairan sekitar tower Tanjung (S: $00^{\circ} 56.55^{\prime} 84^{\prime \prime}$; E: $122^{\circ} 48.01^{\prime} 56^{\prime \prime}$ )

Tabel 2. Kriteria indeks keanekaragaman kategori pencemaran

\begin{tabular}{ccll}
\hline No & $\begin{array}{c}\text { Indeks } \\
\text { Keanekaragaman }\end{array}$ & \multicolumn{1}{c}{ Kategori keragaman } & Kategori pencemaran \\
\hline 1 & $>3$ & Keragaman tinggi & Belum tercemar \\
2 & $2,5-3$ & Keragamanan cukup tinggi & Tercemar ringan \\
3 & $1-<2,5$ & Keragaman sedang & Tercemar sedang \\
4 & $<1$ & Keragaman rendah & Tercemar berat \\
\hline
\end{tabular}

Sumber: Mason (1981) dalam Effendi (2003)

komunitas fitoplankton di perairan Teluk Lalong keanekaragamannya rendah, komunitas biota tidak stabil dan kualitas air tercemar berat. Hal ini sesuai pendapat Mason (1981) dalam Effendi (2003) mengenai kriteria indeks keanekaragaman kategori pencemaran yang terlihat pada Tabel 2.

Rata-rata nilai Indeks Keanekaragaman pada semua stasiun di perairan Teluk Lalong Kota Luwuk tergolong dalam kategori rendah, hal ini mengisyaratkan adanya dominasi suatu spesies terhadap spesies lain. Adanya fitoplankton Nitzschia closterium pada saat setiap pengambilan sampel pada semua stasiun di perairan Teluk Lalong Kota Luwuk memperlihatkan tiap stasiun hampir didominasi oleh fitoplankton dari 1 genus. Dominasi yang cukup besar ini akan mengarah pada komunitas yang labil maupun tertekan. Selain itu diduga bahwa produktivitas di perairan Teluk
Lalong rendah menyebabkan kondisi ekosistem tidak stabil, dan tekanan ekologi tinggi. Menurut Stirn (1981) dalam Pirzan dan Pong-Masak (2008) dan apabila $H^{\prime}<1$, maka komunitas biota dinyatakan tidak stabil, apabila $H^{\prime}$ berkisar 1-3 maka stabilitas komunitas biota tersebut adalah moderat (sedang) dan apabila $\mathrm{H}^{\prime}>3$ berarti stabilitas komunitas biota berada dalam kondsi prima (stabil). Semakin besar nilai $H^{\prime}$ menunjukkan semakin beragamnya kehidupan di perairan tersebut, kondisi ini merupakan tempat hidup yang lebih baik.

Hasil pemeriksaan dan hasil analisis fitoplankton pada enam stasiun (S1, S2, S3, S4, S5 dan S6) yang terdapat di perairan Teluk Lalong Kota Luwuk didapatkan spesies fitoplankton berjumlah 21 spesies, yaitu Nistzchia closterium, Gonatozygon monotonium, Nistzchia vermicularis, Chaetocheros 
$\mathrm{sp}$, Spirulina sp, Cymatopleura solea, Ceratium hirundinella, Goniodoma sp, Trichotoxon reinboldii, Mycrocystis aeruginosa, Gloeotricha echinulata, Eudorina wallichii, Merismopodia minuta, Cylindrocystis brebissonii, Ceratium tripos, Dinophysis miles, Coscinodiscus sp, Eugleuna spirogyra, Calothrix sp, Gonatozygon monotenium dan Peridinium sp. Secara keseluruhan didominasi dari jenis Nitzschia closterium, Gonatozygon monotenium dan Goniodoma sp.

Fitoplankton memiliki klorofil yang berperan dalam fotosintesis untuk menghasilkan bahan organik dan oksigen dalam air yang digunakan sebagai dasar mata rantai pada siklus makanan di laut. Namun fitoplankton tertentu mempunyai peran menurunkan kualitas perairan laut apabila jumlahnya berlebih (blooming) (Anderson, et al., 2008). Tingginya populasi fitoplankton beracun di dalam suatu perairan dapat menyebabkan berbagai akibat negatif bagi ekosistem perairan, seperti berkurangnya oksigen di dalam air yang dapat menyebabkan kematian berbagai makhluk air lainnya (Damar, 2006).

Ledakan populasi fitoplankton yang diikuti dengan keberadaan jenis fitoplankton beracun akan menimbulkan Ledakan Populasi Alga Berbahaya (Harmful Algae Blooms - HABs). Faktor yang dapat memicu ledakan populasi fitoplankton berbahaya antara lain karena adanya eutrofikasi; adanya upwelling yang mengangkat massa air kaya unsur-unsur hara; adanya hujan lebat dan masuknya air ke laut dalam jumlah yang besar (Wiadnyana, 1996). Beberapa penyakit akut yang disebabkan oleh racun dari kelompok fitoplankton berbahaya adalah Paralytic Shellfish Poisoning (PSP), Amnesic Shellfish Poisoning (ASP), dan
Diarrhetic Shellfish Poisoning (DSP). Racun-racun tersebut sangat berbahaya karena di antaranya menyerang sistem saraf manusia, pernapasan, dan pencernaan. Semua penyakit di atas berkaitan dengan konsumsi kerang oleh manusia (Praseno dan Sugestiningsih, 2000). Nitzschia sp. merupakan spesies penyebab Amnesic Shellfish Poisoning (ASP) yang mengeluarkan toksin asam domoic. Toksin yang diproduksi dapat memasuki rantai makanan hingga ke tubuh manusia melalui perantara kerang. Kerang merupakan organisme bentuk suspension feeder yang menyaring plankton yang melimpah di kolom air (Nybakken, 1992).

Spesies HABs yang paling banyak ditemukan berasal dari kelas Dinophyceae. Hal ini dikarenakan Dinophyceae dapat membentuk sista (cyst) sebagai tahap istirahat, sista ini mengendap di dasar laut dan istirahat sampai kondisi lingkungan mendukung kembali untuk tumbuh (Nontji, 2006). Anggota dari kelompok ini diketahui paling banyak mempunyai jenis-jenis toksik (Praseno dan Sugestiningsih, 2000). Chaetoceros sp., spesies HABs tertinggi kedua setelah Nitzschia sp., merupakan spesies fitoplankton yang tidak toksik terhadap manusia tetapi secara fisik dapat mengganggu sistem pernafasan ikan dan avertebrata terutama apabila kepadatan individunya relatif tinggi. Diatom jenis ini mempunyai morfologi khas yaitu duri. Duri-duri tersebut dapat merangsang pembentukan lendir pada insang biota laut, sehingga biota tersebut sukar bernafas. Duri-duri ini bahkan dapat menyebabkan pendarahan di insang (Praseno dan Sugestiningsih, 2000). Chaetoceros merupakan jenis fitoplankton yang diketahui mampu bertahan di perairan tercemar (Fachrul et al., 2005). 


\section{Kualitas Air}

Hasil kisaran pengukuran parameter lingkungan di perairan Teluk Lalong Kota Luwuk Kabupaten Banggai yang meliputi $\mathrm{pH}$, suhu, salinitas, dan kecerahan tertuang pada Tabel 3.

Hasil analisis Tabel 3 menunjukkan bahwa nilai suhu perairan pada ke enam stasiun di perairan Teluk Lalong Kota Luwuk berkisar antara 27-33 ${ }^{\circ} \mathrm{C}$ sedangkan nilai $\mathrm{pH}$ berkisar antara 8,2-8,7, hal ini menunjukkan bahwa suhu dan $\mathrm{pH}$ di perairan Teluk Lalong Kota Luwuk masih berada di kisaran normal. Davis (1991) dalam Rashidy et al. (2013) menyatakan bahwa rata-rata pH air laut adalah bervariasi walaupun tidak terlalu besar yaitu berkisar 7,8-8,7.

Sebaran salinitas di perairan Teluk Lalong Kota Luwuk berkisar antara 22-32 ppt. Menurut Tarigan dan Edward (2003) dalam Rashidy et al. (2013) bahwa salinitas di perairan Indonesia pada umumnya berkisar antara 30-35 ppt, sedangkan untuk laut terbuka salinitasnya > 34 ppt. Salinitas di perairan Teluk Lalong Kota Luwuk masih sesuai dengan kisaran salinitas pada umumnya di perairan
Indonesia, rendahnya salinitas pada salah satu stasiun pengambilan sampel (22 ppt) di perairan Teluk Lalong Kota Luwuk hal ini karena dekat dengan rumah penduduk dan muara sungai. Tingkat kecerahan pada setiap stasiun $>4$ meter, menunjukkan bahwa daya tembus cahaya matahari ke perairan pada saat pengambilan sampel tinggi. Romimohtarto dan Juwana (2004), menyebutkan kecerahan adalah daya tembus cahaya matahari ke suatu perairan, dalam hal ini adalah jarak tembus cahaya kedalam suatu perairan.

\section{KESIMPULAN}

Berdasarkan hasil penelitian dan pembahasan dapat disimpulkan bahwa :

1. Fitoplankton berjumlah 21 spesies, yaitu Nistzchia closterium, Gonatozygon monotonium, Nistzchia vermicularis, Chaetocheros sp, Spirulina sp, Cymatopleura solea, Ceratium hirundinella, Goniodoma sp, Trichotoxon reinboldii, Mycrocystis aeruginosa, Gloeotricha echinulata, Eudorina wallichii, Merismopodia minuta, Cylindrocystis

Tabel 3. Kisaran parameter kualitas air pada masing-masing stasiun di perairan Teluk Lalong Kota Luwuk

\begin{tabular}{|c|c|c|c|c|c|c|c|}
\hline \multirow{2}{*}{ Parameter } & \multirow{2}{*}{ Satuan } & \multicolumn{6}{|c|}{ Stasiun } \\
\hline & & S1 & S2 & S3 & S4 & S5 & S6 \\
\hline Suhu & ${ }^{\circ} \mathrm{C}$ & $27-32$ & $29-33$ & $29-32$ & $30-32$ & $30-31$ & $30-31$ \\
\hline $\mathrm{pH}$ & & $8,4-8,7$ & $8,3-8,7$ & $8,2-8,7$ & $8,2-8,6$ & $8,2-8,7$ & $8,3-8,7$ \\
\hline Salinitas & Ppt & $30-32$ & $30-32$ & $29-32$ & $24-31$ & $22-30$ & 30 \\
\hline Kecerahan & Meter & $4-5$ & $4-5$ & $>10$ & $4-7$ & $6-10$ & $>10$ \\
\hline
\end{tabular}

\begin{tabular}{ll}
\hline Keterangan : & : Perairan depan pelabuhan peti kemas (S : $00^{\circ} 57.13^{\prime} 25^{\prime \prime} ;$ E: $\left.122^{\circ} 47.41^{\prime} 21^{\prime \prime}\right)$ \\
S1 & : Perairan depan gedung DPRD (S: $\left.00^{\circ} 57.11^{\prime} 98^{\prime \prime} ; \mathrm{E}: 122^{\circ} 47.31^{\prime} 38^{\prime \prime}\right)$ \\
S2 & : Perairan depan CFC (S: $\left.00^{\circ} 57.12^{\prime} 65^{\prime \prime} ; \mathrm{E}: 122^{\circ} 47.31^{\prime} 49^{\prime \prime}\right)$ \\
S3 & : Perairan depan muara Sungai Maleo (S: $\left.00^{\circ} 57.02^{\prime} 32^{\prime \prime} ; \mathrm{E}: 122^{\circ} 47.38^{\prime} 08^{\prime \prime}\right)$ \\
S4 & : Perairan depan rumah makan Pasar Tua (S: $\left.00^{\circ} 56.54^{\prime} 57^{\prime \prime} ; \mathrm{E}: 122^{\circ} 47.51^{\prime} 31^{\prime \prime}\right)$ \\
S5 & : Perairan sekitar tower Tanjung (S : $\left.00^{\circ} 56.55^{\prime} 84^{\prime \prime} ; \mathrm{E}: 122^{\circ} 48.01^{\prime} 56^{\prime \prime}\right)$
\end{tabular}


brebissonii, Ceratium tripos, Dinophysis miles, Coscinodiscus sp, Eugleuna spirogyra, Calothrix $\mathrm{sp}$, Gonatozygon monotenium dan Peridinium sp. Secara keseluruhan didominasi dari jenis Nitzschia closterium, Gonatozygon monotenium dan Goniodoma sp

2. Berdasarkan rata-rata nilai Indeks Keanekaragaman (berkisar antara 0,62-1,06), perairan Teluk Lalong dikategorikan tercemar sedang dan tercemar berat.

3. Rata-rata kisaran parameter kualitas air di perairan Teluk Lalong Kota Luwuk yang meliputi suhu, $\mathrm{pH}$, salinitas dan kecerahan masih dalam kisaran normal untuk kehidupan fitoplankton dimana suhu berkisar antara 27$33^{\circ} \mathrm{C}, \mathrm{pH}$ berkisar antara $8,2-8,7$, salinitas berkisar antara 22-32 ppt dan kecerahan lebih dari 4 meter.

\section{DAFTAR PUSTAKA}

Anderson, D,M., et al. 2008. Harmful Algall Blooms And Eutrophication: Examining Linkages From Selected Coastal Region Of The United Stated, Harmful Algae. 8. 39-53.

Basmi. 2000. Planktonologi : Plankton Sebagai Indikator Kualitas Perairan. Fakultas Perikanan dan IImu Kelautan. Institut Pertanian Bogor. $60 \mathrm{hlm}$.

Boyd, C.E. 1979. Water Quality in Warmwater Fish Ponds. Auburn University Agricultural Experiment Station. Auburn, Alabama, USA. $359 \mathrm{hlm}$.

Clark, W., and P.L. Hosking. 1986. Statical Methods for Geographers. New York: John Wiley and Sos, Inc.

Damar, A. 2006. Musim Hujan Dan Eutrofikasi Perairan Pesisir. Majalah Tempo. 30 Nopember 2006.

Effendi, H. 2003. Telaah Kualitas Air. Kanisius. Yogyakarta.
Fachrul, M F, Haeruman H, Sitepu L C, 2005. Komunitas Fitoplankton Sebagai Bioindikator Kualitas Perairan Teluk Jakarta. Seminar Nasional MIPA. Universitas Indonesia. Jakarta.

Newel, G.E. and R.C. Newel. 1977. Marine Plankton. London: Hutchintson.

Nontji, A.. 2006. Tiada Kehidupan Di Muka Bumi Tanpa Plankton. Pusat Penelitian Oseanografi - LIPI. Jakarta.

Nybakken, J.W. 1992. Biologi Laut Suatu Pendekatan Ekologis. PT. Gramedia. Jakarta. 459 hal.

Odum, P.E. 1971. Fundamentals of Ecology. Saunders College Publishing. Rinehart and Winston, Inc. Translation Copyright 1993 by Gadjah Mada University Press.

Pirzan, A.M. dan P.R. Pong-Masak. 2008. Hubungan Keragaman Fitoplankton dengan Kualitas Air di Pulau Bauluang, Kabupaten Takalar, Sulawesi Selatan. BIODIVERSITAS.Volume 9, Nomor 3 Juli 2008. Hal: 217-221.

Praseno, D,P. dan Sugestiningsih. 2000. Red Tide Di Perairan Indonesia. Pusat Penelitian dan Pengembangan Oseanologi - LIPI. Jakarta.

Rashidy, E. A., Litaay M., Salam M.A. dan Umar M. R. 2013. Komposisi Dan Kelimpahan Fitoplankton Di Perairan Pantai Kelurahan Tekolabbua, Kecamatan Pangkajene, Kabupaten Pangkep, Provinsi Sulawesi Selatan. Jurnal Alam Dan Lingkungan. Vol.4 (7) Agustus 2013.

Romimohtarto, K \& S. Juwana. 2004. Meroplankton Laut. Penerbit Djambatan. Jakarta.

Sachlan, M. 1982. Planktonologi. Direktorat Jenderal Perikanan Departemen Kelautan dan Perikanan. Jakarta. $101 \mathrm{hlm}$

Wiadnyana, N,N. 1996. Mikroalga Berbahaya Di Indonesia. Oseanology dan Limnology di Indonesia. 29. $15-28$.

Yamaji. J. 1976. Illustration of Marine Plankton. Osaka: Hoikush Publishing Co. Ltd. 